\title{
TEXTURE CHANGES IN APPLE CULTIVARS DURING STORAGE IN DIFFERENT CONDITIONS
}

\author{
Rafał NADULSKI ${ }^{1}$, Katarzyna WRÓBLEWSKA-BARWINSKA ${ }^{1}$, \\ Dorota DOMAGAŁA ${ }^{2}$, Zbigniew KOBUS ${ }^{1}$, Kamil WILCZYŃSKI ${ }^{1}$ \\ ${ }^{1}$ Department of Food Engineering and Machines, University of Life Sciences in Lublin, POLAND \\ ${ }^{2}$ Department of Applied Mathematics and Computer Science, University of Life Sciences in Lublin, \\ POLAND \\ E-mail of corresponding author: rafal.nadulski@up.lublin.pl
}

Keywords: apple, texture, storage, time, fruit farm

\begin{abstract}
In Poland, apples are stored in cold storage plants, with either normal or controlled atmosphere. Estimation of physical parameters permits the determination of the current state of the fruit and the prediction of allowable periods of commercial turnover after storage. The objective of the study was to characterise, on the basis of experimental studies, the firmness of the flesh and the skin strength in the puncture test of apple cultivars Ligol, Gloster, Golden Delicious, and Jonagored held in cold storage under different conditions. Apple storage conditions have a decisive effect on the preservation of the texture. In the course of cold storage of apples there takes place an unfavourable change in the analysed parameters of their texture The dynamics of changes in the analysed values characterising the texture was related to the varietal traits of the fruits.
\end{abstract}

\section{INTRODUCTION}

With apple harvest of over 3 million tons a year, Poland ranks among the largest producers of the fruit in Europe. In Poland, apples are stored in cold storage plants, with either normal or controlled atmosphere. Estimation of physical parameters permits the determination of the current state of the fruit and the prediction of allowable periods of commercial turnover after storage (Johnston, Hewett, Banks, Harker, Hertog 2001; Nadulski, 2009). In practice, the estimation of textural properties of fruit is conducted primarily with the use of empirical tests consisting, among other things, in the determination of fruit firmness with the Magness-Taylor method and of skin strength in the skin puncture test, as well as imitation application of the TPA test (Bourne, 2002; Surmaka-Scześniak, 2002). However, the textural properties of apples depend to a large extent on pre-harvest and post-harvest factors, and the time of harvest of the fruits has a significant effect on the storage capacity of the fruits and on their properties during storage (Saei, Tustinc, Zamania, Talaiea, Halld, 2011; Costa, Cappellin, Fontanari, Longhi., Guerra, Magnago, Gasperi, Biasioli 2012). In long-term storage of fruits, specific requirements concerning temperature, humidity and the amount of oxygen and carbon dioxide in the storage plant have to be met (Weber, Brackmann, Anese, Both, Pavanello, 2012). Non-observance of the technological regime during storage in cold storage plants with controlled atmosphere may lead to fruit damage (Saquet and Streif 2008). From the viewpoint of the producer, it is important to have fruits in commercial turnover before their firmness drops to a level that would be unacceptable to the consumer (Płocharski and Konopacka 1999). Therefore, it is necessary to acquire knowledge on changes in the textural properties of particular apple cultivars in the course of storage in cold storage plants with normal and controlled atmosphere.

The objective of the study was to characterise, on the basis of experimental studies, the firmness of the flesh and the skin strength in the puncture test of apple cultivars Ligol, Gloster, Golden Delicious, and Jonagored held in cold storage under different conditions. 


\section{MATERIAL AND METHODS}

The experimental material consisted of fruits of four apple cultivars (Malus domestica Borkh.): Gloster, Golden Delicious, Jonagored, Ligol). The material originated from a specialist orchard farm belonging to the Association of Fruit Producers "Stryjno Sad". The material selected for the tests was of similar fruit size, healthy, without mechanical damage, from the harvests of the years 2011/2012.

The material used in the experiments was stored for 220 days in a cold storage plant with normal atmosphere (NA) and in a cold storage plant with reduced oxygen level (ULO). The first series of tests was performed immediately after the harvest, and subsequent tests at 30-day intervals. In the normal storage plant the temperature was maintained at 1.7$2.5^{\circ} \mathrm{C}$ and humidity at the level of $86-92 \%$, while in the chamber with atmosphere with reduced oxygen level (ULO) the temperature was $1.6-2.2^{\circ} \mathrm{C}$ and the humidity was $90 \%$ $92 \%$. The atmosphere consisted of the following gases with percentage rates of $1,6 \%-$ oxygen, 2,2\% - carbon dioxide, and nitrogen.

The textural tests were performed with the use of the Texture Analyser TA-TX2, Stable Micro Systems Ltd. (Great Britain), equipped with measuring head with operation range up to $0.5 \mathrm{kN}$. The tests were made using a penetrometer with diameter of $11.1 \mathrm{~mm}$ and a cylindrical tip with convex face (conforming to the Magness-Taylor apparatus) for the penetration of apple flesh, and a penetrometer with diameter of $5 \mathrm{~mm}$ and a flat-faced cylindrical tip for the apple skin puncture tests. The penetration tests were conducted on fruits with a layer of skin removed to achieve penetration of $8 \mathrm{~mm}$. The skin puncture test was made on the largest-diameter perimeter of the fruits, until the penetrometer penetrated the fruit flesh to the depth of $8 \mathrm{~mm}$. Statistical analysis of the results was made using the software package Statistica 12.0 (StatSoft Inc., Tulsa, OK, USA), using the analysis of variance and regression analysis.

\section{RESULTS}

Apple storage in the storage plant with normal atmosphere caused a very big loss of fruit flesh firmness at the end of the period of storage (Fig. 1).

The greatest loss of firmness of $58.8 \%$ was recorded in the case of fruits of cv. Ligol, and the lowest $-47.9 \%$ - in the case of cv. Jonagored. The firmness of the flesh of fruits of cultivars Gloster and Golden Delicious decreased by approximately 55-56\%.

Analysis of the graphs indicates that in the course of apple storage in the cold storage plant with controlled atmosphere there takes place a gradual decrease of the firmness of the fruits (Fig. 2). At the end of the period of storage in the cold storage plant with controlled atmosphere a $31.9 \%$ decrease of flesh firmness was noted in the case of fruits of cv. Gloster, $28.1 \%$ in the case of cv. Golden Delicious, $14.9 \%$ in the case of cv. Jonagored, and a $10.6 \%$ decrease of flesh firmness in the case of cv. Ligol. 
a)

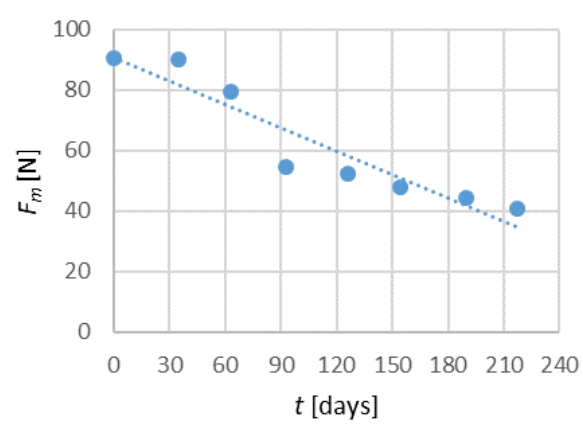

c)

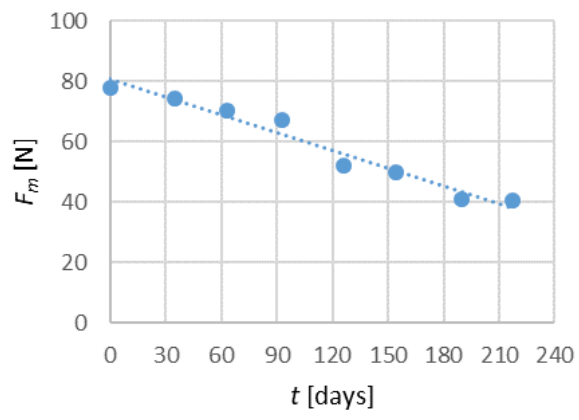

b)

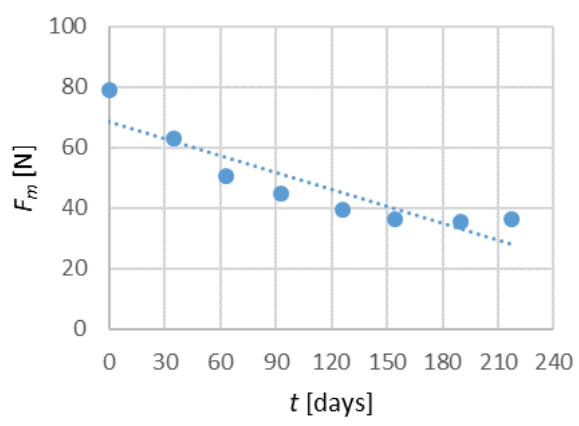

d)

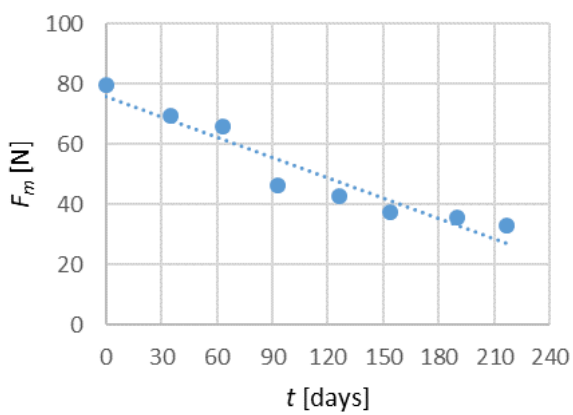

Fig. 1. Mean values of force $F_{m}$ (firmness) for flesh tissue of apples of cultivars Gloster (a), Golden Delicious (b), Jonagored (c), Ligol (d) in relation to the time of storage in cold storage plant with normal atmosphere (NA)

a)

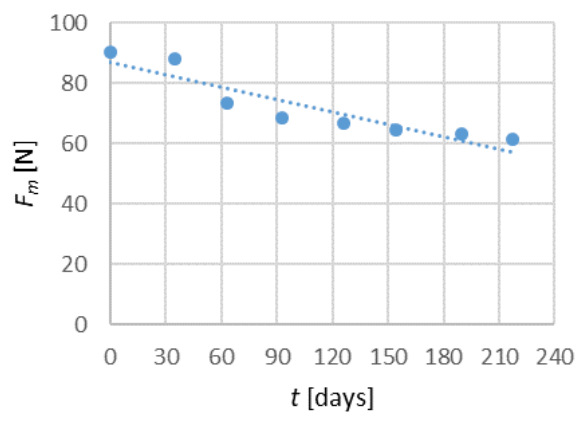

c)

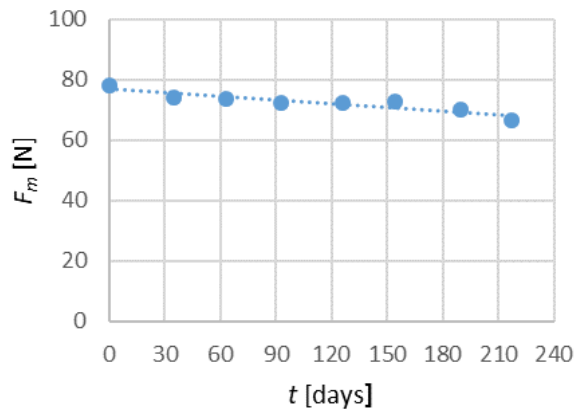

b)

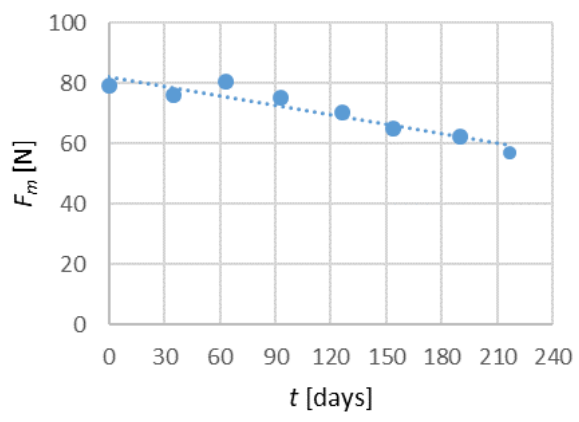

d)

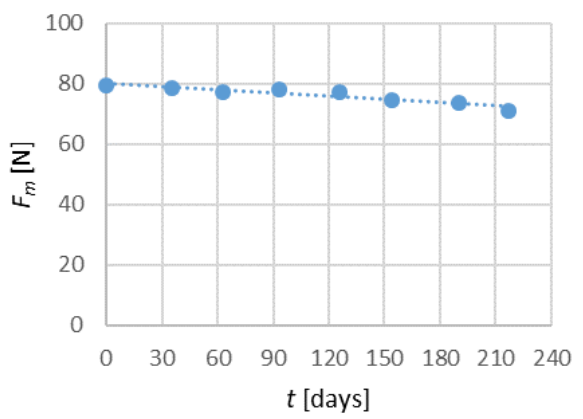

Fig. 2. Mean values of force $F_{m}$ (firmness) for flesh tissue of apples of cultivars Gloster (a), Golden Delicious (b), Jonagored (c), Ligol (d) in relation to the time of storage in cold storage plant with controlled atmosphere (ULO) 
In the course of fruit storage in the cold storage plant with normal atmosphere, a distinct decrease was recorded in the value of force required to puncture the skin (Fig. 3). At the end of the period of storage the value of the force required for apple skin puncture, in the case of all apple cultivars tested, decreased to the level of 17.3-19.9 N. The greatest decrease of skin strength was noted in the case of apples cv. Golden Delicious, for which it amounted to $48.6 \%$, while in the case of the remaining cultivars the decrease was in the range of $32.6-39.7 \%$.

a)

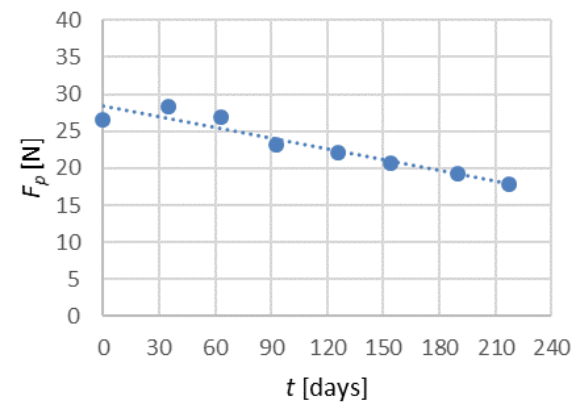

c)

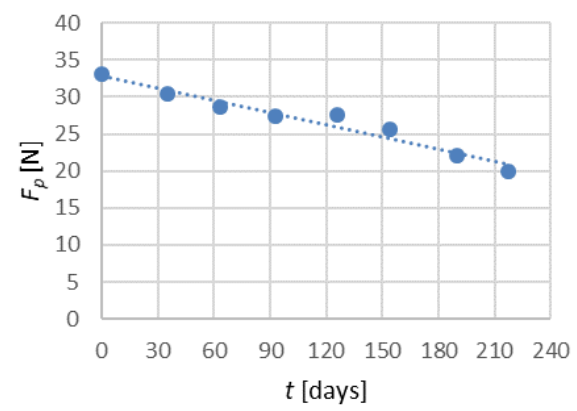

b)

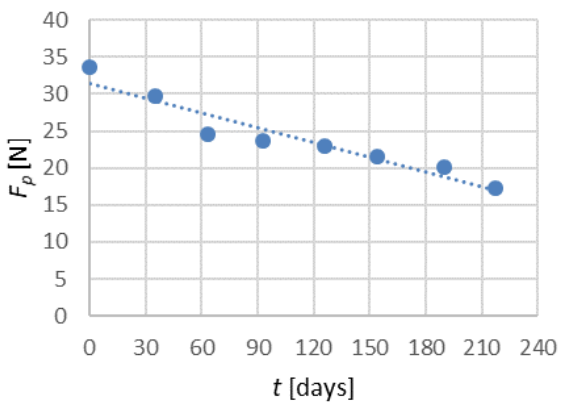

d)

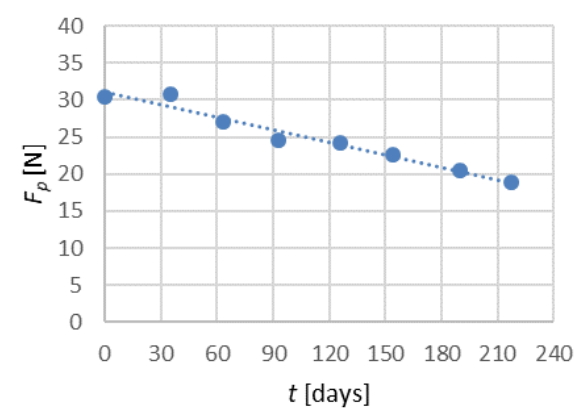

Fig. 3. Mean values of skin puncture force $F p$ for apples of cultivars Gloster (a), Golden Delicious (b), Jonagored (c), Ligol (d) in relation to the time of storage in cold storage plant with normal atmosphere (NA)

During fruit storage in the cold storage plant with controlled atmosphere the value of the force required for fruit skin puncture decreased only to a small degree (Fig. 4). The greatest decrease in skin strength was recorded in the case of cv. Gloster $-27.1 \%$ and cv. Golden Delicious $-21.1 \%$, and the smallest in the case of cv. Jonagored $-13.5 \%$ and cv. Ligol $-13.5 \%$.

At the end of the period of storage decidedly the lowest resistance to skin puncture was characteristic of the fruits of cv. Gloster $-19.3 \mathrm{~N}$. The resistance to skin puncture noted for the other apple cultivars was at a fairly similar level and fell within the range of 26.1$28.6 \mathrm{~N}$.

Irrespective of the conditions of storage, all the parameters of apple texture during the storage were described by means of linear regression equations, obtaining very good fit of the equations to measured values.

In conclusion, it can be stated that apple flesh firmness and skin puncture force depend significantly on the time and conditions of fruit storage. In addition, statistical analysis of the results showed that the range and character of changes in the parameters tested depended also on the varietal traits of the fruits. 
a)

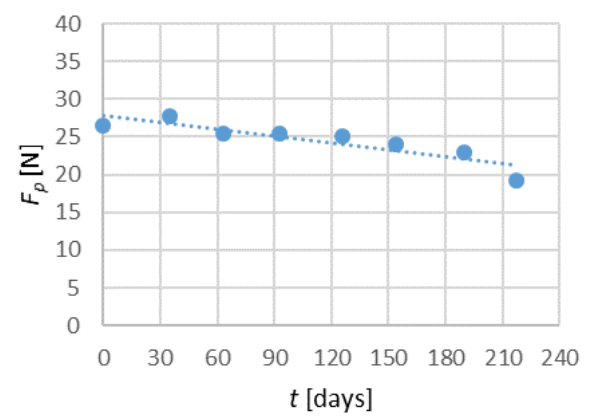

c)

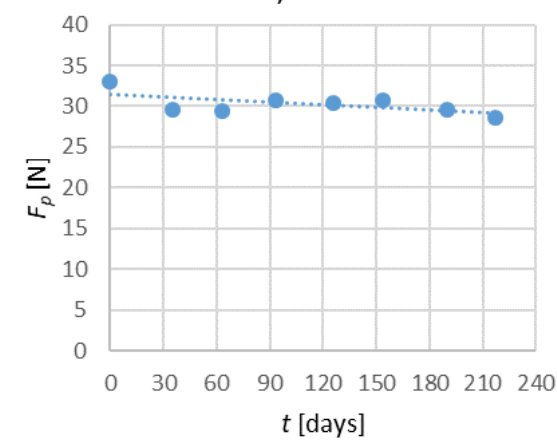

b)

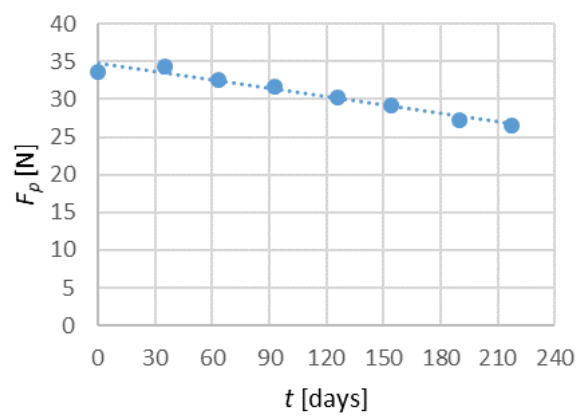

d)

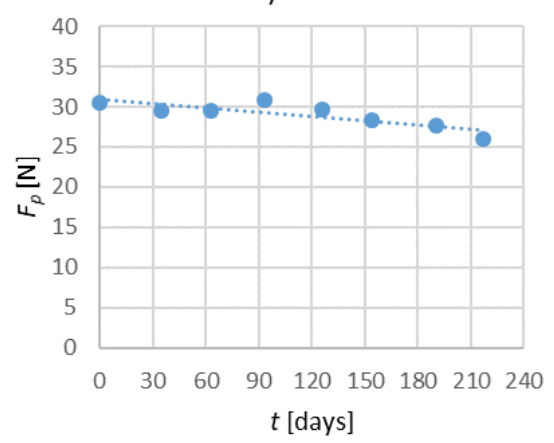

Fig. 4. Mean values of skin puncture force $F_{p}$ for apples of cultivars Gloster (a), Golden Delicious (b), Jonagored (c), Ligol (d) in relation to the time of storage in cold storage plant with controlled atmosphere (ULO)

\section{CONCLUSIONS}

In the course of cold storage of apples, an unfavourable change in the analysed parameters of their texture takes place. Apple storage conditions have a decisive effect on the preservation of the texture. The range of changes in the values of the analysed texture parameters of apples stored in the cold storage plant with controlled atmosphere was decidedly smaller compared to the changes in the texture of fruits stored in the cold storage plant with normal atmosphere. The dynamics of changes in the analysed values characterising the texture was related to the varietal traits of the fruits. In the case of storage in the normal cold storage plant, among the apple cultivars under study the smallest range of changes in the analysed texture parameters was determined for cultivars Ligol and Jonagored. The dynamics of changes in the values of texture parameters of apples stored in the cold storage plant with controlled atmosphere depended on the varietal traits of the apples to a smaller degree. Relatively the smallest range of changes in the texture parameters of apples stored in the cold storage plant with controlled atmosphere was noted in the case of cultivars Ligol and Jonagored. In the course of apple storage in the cold storage plant with controlled atmosphere a constant gradual decrease in the values of the analysed texture parameters was observed throughout the period of storage, while in the case of fruits stored in the cold storage plant with normal atmosphere the greatest range of changes in the texture parameters took place in the initial stage of storage, after which the rate of the changes decreased notably.

Knowledge on the changes in apple texture during storage allows to empty the cold storage chambers at a suitable time and sell the fruits, which in effect reduces the costs operation of cold storage facilities at orchard farms. 


\section{REFERENCES}

Bourne, M. C. (2002). Food Texture and Viscosity: Concept and Measurement. Second Edition. Academic Press, London, 423.

Costa F., Cappellin L., Fontanari M., Longhi S., Guerra W., Magnago P., Gasperi F., Biasioli F. (2012). Texture dynamics during postharvest cold storage ripening in apple (Malus $\times$ domestica Borkh.). Postharvest Biology and Technology, 69, 54-63.

Johnston J. W., Hewett E. W., Banks N. H., F. Harker F. R., Hertog M. L. A. T. M. (2001). Physical change in apple texture with fruit temperature: effects of cultivar and time in storage. Postharvest Biology and Technology, 23, 13-21.

Nadulski R. (2009). Wpływ czasu i warunków przechowywania jabłek na ich wybrane właściwości mechaniczne. Inżynieria Rolnicza, 2(111), 107-116 (in polish).

Płocharski W. J., Konopacka D. (1999). The relation between mechanical and sensory parameters of apples. Acta Horticulturae, 485, 309-318.

Saei A., Tustinc D. S., Zamania Z., Talaiea A., Halld A. J. (2011). Cropping effects on the loss of apple fruit firmness during storage: The relationship between texture retention and fruit dry matter concentration. Scientia Horticulturae, 130, 256-265.

Saquet A. A.; Streif J. (2008). Fermentative metabolism in 'Jonagold' apples under controlled atmosphere storage. European Journal of Horticultural Science, 73, 43-46.

STATISTICA (Data Analysis Software System), v. 6.1, StatSoft, Inc, Tulsa, OK, USA; http://www.statsoft.com. (2003).

Surmacka-Szcześniak A. (2002). Texture is a sensory property. Food Quality and Preference, 13, 215-225.

Weber A., Brackmann A., Anese R. O., Both V., Pavanello E. P. (2012). 'Royal Gala' apple quality stored under ultralow oxygen concentration and low temperature conditions. Pesquisa Agropecuária Brasileira, 46(2), 1597-1602. 